\title{
Effect of Aqueous Neem Extract on Development of Pestalotia heterocornis Agent of Pestalotia Leaf Blight of Cashew in Far North Cameroon
}

\author{
Jules Patrice Ngoh Dooh, Pavel Rony Mbou Tadzo, Placide Deurnaye, \\ Gabriel Djongnang, and Zachee Ambang
}

\section{ABSTRACT}

Cashew (Anacardium occidentale L.) trees are threatened by my many fungal diseases, among which pestaliotiopsis occupies an important place in terms of damage created in Cameroon. The aim of the present study is to evaluate the effects of aqueous extract of neem seed (AENS) on the development of Pestalotia heterocornis, the causative agent of pestalotiopsis of cashew. Isolates of $P$. heterocornis were obtained from diseased cashew leaves collected in the orchads. The concentrations of AENS were $C_{1}=$ $500 \mu \mathrm{g} / \mathrm{ml}, C_{2}=50 \mu \mathrm{g} / \mathrm{ml}$ and $\mathrm{C}_{3}=5 \mu \mathrm{g} / \mathrm{ml}$. Mancozeb $80 \mathrm{WP}(\mathrm{Mz})$ was used as positive control. Effect of Mancobeb 80WP on the growth and spore germination of isolates were performed. The effect of AENS on the plants was evaluated in vivo. Four (4) isolates of $P$. heterocornis were used. AENS $C_{1}$ concentration reduced the growth of all isolates. The percentage of inhibition was ranged from 45 to $90 \%$ with the other concentrations. AENS did not inhibited spore germination $(0.0 \%)$. But Mz totally inhibited conidia germination of all isolates. In vivo, AENS protected plants against $P$. heterocornis. AENS can be integrated in management of cashew plants against $P$. heterocornis.

Keywords: Anacardium occidentalis L, Pestalotia heterocornis, neem extract, Mancozeb, inhibition.

\section{INTRODUCTION}

Cashew tree (Anacardium occidentale L.) is a tropical plant native to Brazil [1]. Its cultivation contributes to the socio-economic development of several countries in the world [2].

The nut, which is the main commercial product, is used in food, cosmetics, medicine, and automotive industry [3]. It also participates in the conservation of biodiversity and the reconstitution of degraded and impoverished crop lands.

Ivory Coast has become the world's largest producer and exporter of cashew nuts with more than 700 thousand tons ahead of India, Vietnam, and Brazil [4]. Cameroon is not cited among these major producing countries in Africa. Cashew was introduced through the National Fund for Rural Development (FONADER) in 1972 [5]. However, its culture is only conducive to the three northern regions of the country namely Adamawa, the North and the Far North. Currently, due to growing demand, many projects to extend its cashew nuts.
Submitted : March 10, 2021

Published : May 03, 2021

ISSN: $2684-1827$

DOI: 10.24018 /ejfood.2021.3.3.231

Jules Patrice Ngoh Dooh*

Department of Biological Sciences, Faculty of Science, University of Maroua, Cameroon.

(e-mail: ndjuliopat ${ }^{@}$ yahoo.fr)

Pavel Rony Mbou Tadzo

Department of Biological Sciences,

Faculty of Science, University of Maroua,

Cameroon.

(e-mail: mboutadzopavelrony@gmail.com) Placide Deurnaye

Department of Biological Sciences,

Faculty of Science, University of Maroua,

Cameroon.

(e-mail: pdeurnaye@ gmail.com)

Gabriel Djongnang

Department of Biological Sciences, Faculty of Science, University of Maroua, Cameroon.

(e-mail: gabriel.djongnang ${ }^{\circledR}$ gmail.com)

Zachee Ambang

Laboratory of Biotechnologies, Phytopathology and Microbiology Unit, University of Yaounde I, Cameroon.

(e-mail: zachambang@yahoo.fr)

*Corresponding author

cultivation to other regions such as the East and Center of the country are underway [5].

Today, cashew nuts are a growing cash crop and represent a great opportunity for Africa through the export of its nuts [6]. Its global production has almost doubled in less than a decade, from $2,361,384$ tons in 2002 to $4,152,315$ tons in 2012 [7]. Despite the enormous potential for financial income from cashew nut sales worldwide [7], cashew nut production in Cameroon is still very low [5]. Currently, there is a document on the "National Strategy for the Development of Cashew Value Chains in Cameroon 2019-2023" which highlights Cameroon's potential to produce and export

Unfortunately, cashew is threatened by many biotic and abiotic constraints that are accompanied by yield losses. Among the biotic constraints, diseases and pests are the most detrimental and compromise cashew yield in terms of quality [8]. Depending on variety, production area and season, yield losses are estimated to be in the order of 70-100\% in Benin 
[9]. In addition, lack of maintenance of agricultural fields also hinders production [10]. The poor quality of nuts used as seed, post-harvest losses, inadequate storage places for nuts decrease the purchase price of nuts [11].

In the Far North region, particularly in the locality of Maroua, several diseases including fungal, bacterial, algal, and viral diseases have been identified [12]. Anthracnose and pestalotiopsis are the most dangerous diseases with an incidence of $85.33 \%$ and $96.66 \%$ respectively [9], [12].

The agent responsible of pestalotiopsis is $P$. heterocornis, a highly fungus that attacks a variety of crops such as guava, pecan, and strawberry [13]. The fungus infects leaves and reduces orchard yields [14]. Necrosis appeared on leaves which can drop and cause a reduction in plant photosynthetic surface area.

Chemical control is the most effective global method against cashew nut diseases [14], [15]. However, fungicides unfortunately have consequences on the environment, human health and develop resistance of microorganisms [16].

Alternatives to chemical control, including biological control, are thus being considered. The latter comprises two approaches, including the use of antagonistic microorganisms and the use of plant extracts. Plants have already proven their effectiveness against several fungi [17]-[19].

Neem extract is known for its insecticidal [21], [22] and fungicidal [19], [22] properties. These two characteristics could open up a new avenue in the protection of crops that are generally subject to a pest complex. The general objective of this work is to evaluate the effect of aqueous neem extract against Pestalotia heterocornis, the agent responsible for cashew nut pestaliosis in the Far North of Cameroon.

\section{MAterials AND Methods}

\section{A. Plant Materials}

The plant material consisted mainly of cashew tree leaves taken from diseased plants from the orchards of the commune of Maroua I, three-month-old cashew tree seedlings purchased from nurseries and neem (Azadirachta indica) seeds collected in the town of Maroua and neem seeds.

\section{B. Sampling and Obtention of Isolates}

Leaves showing symptoms of pestalotia leaf blight were sampled at the level of affected plants using a knife in each orchard surveyed. Each sample was then placed in a plastic bag and transported to the laboratory.

In the laboratory, after washing the samples under running water, they were disinfected by soaking them in a diluted $2 \%$ sodium hypochlorite solution for 3 minutes and then cut into 8 pieces of $0.5 \mathrm{~cm}$. The fragments were then rinsed 3 times with sterile distilled water.

The disinfected leaf fragments were introduced into Petri dishes containing the water agar (WA) medium. After the mycelium had formed around the fragments, $0.8 \mathrm{~cm}$ mycelium discs were removed and transferred to PDA media boxes with a handle and hermetically sealed.

Incubation took place at room temperature under a 12/12 photoperiod for 4 to 7 days [23]. After incubation, the pure cultures were obtained by successive transplantation of the mycelium into new Petri dishes containing PDA medium.
Identification keys were used to identified isolates of $P$. heterocornis [24]-[26].

\section{Characterization of Isolates}

Growth mycelia and pathogenicity tests were performed to characterize different isolates retained for this study.

\section{Evaluation of the radial growth of the different selected isolates}

Three isolates were retained. The mycelial diameter of each isolate was measured daily from 48 hours after culture, using a rule graduated in $\mathrm{cm}$ on the back of the Petri dish. The mycelial growth diameter of each isolate was then calculated using the formula of Singh et al. [27] which follows:

$$
D=\frac{d_{1}+d_{2}}{2}-d_{0}
$$

where do is the diameter of the mycelial disc; $\mathrm{d} 1$ and $\mathrm{d} 2$ are the perpendicular diameters of the fungus and $\mathrm{D}$ is the mycelial growth diameter of each isolate.

\section{Evaluation of pathogenicity of P. heterocornis isolates}

The pathogenicity of the different isolates was assessed by the whole leaf detached test. A total of 12 leaves at a rate of 3 leaves per isolate were collected from plants aged about 3 months.

The leaves were first washed with tap water, then with $1 \%$ sodium hypochlorite for 30 seconds and rinsed three times in sterile distilled water. They were kept during $12 \mathrm{~h}$ application of the spores in a room with transparent polystyrene trays containing sterile filter paper soaked with sterile distilled.

Calibrated using a hematimeter at $3-4,10^{5}$ spores $/ \mathrm{ml}$, a conidial suspension of each isolate was applied to the underside of the leaves and incubated for 14 days at room temperature. Koch postulate was applied by re-isolating isolates from infected leaves.

The modified sensitivity scale developed by [28] was used to evaluate severity of each isolate. The severity index was calculated based on a sensitivity scale. Where, 0 : absence of symptoms; 1 : small points of penetration; 2 : network points; 3: necrosis diameter between $0.5-1 ; 4$ : necrosis diameter between $1-2 ; 5$ : necrosis diameter $>2-3$.

\section{Assessment of the Effect of AENS on Development of Pestalotia Heterocornis in vitro}

\section{Preparation of the different concentrations}

A stock AENS solution of $0.01 \mathrm{~g} / \mathrm{ml}$ concentration was prepared by solubilizing $2 \mathrm{~g}$ of powder in $200 \mathrm{ml}$ of sterile distilled water. Different concentrations were obtained by adding 9, 0.9 and $0.09 \mathrm{ml}$ of the stock solution to $171,179.1$ and $179.91 \mathrm{ml}$ of PDA culture media, respectively, for a final volume of $180 \mathrm{ml}$. The different concentrations $\mathrm{C}_{1}=500 \mu \mathrm{g} / \mathrm{ml}, \mathrm{C}_{2}=50 \mu \mathrm{g} / \mathrm{ml}$ and $\mathrm{C}_{3}=5 \mu \mathrm{g} / \mathrm{ml}$ were obtained. A concentration of $5 \mu \mathrm{g} / \mathrm{ml}$ of Mancozeb $80 \mathrm{WP}$ were also elaborated.

\section{Evaluation of the effect of AENS on the growth of different isolates}

Using a punch, $8 \mathrm{~mm}$ diameter mycelial discs were taken from 6-7-day old cultures and placed in the center of each Petri dish containing the previously prepared media. Incubation took place at room temperature, at a photoperiod 
of $12 / 12$. For each treatment, the experiment was repeated 3 times. Radial diameter measurements of each isolate were made daily starting 48 hours after the mycelial discs were cultured. At the end of the experiment, the inhibition percentages I $(\%)$ of the different concentrations of AENS were determined using the formula:

$$
\mathrm{I}(\%)=\frac{D c(\mathrm{~cm})-D f(\mathrm{~cm})}{D c(\mathrm{~cm})} \times 100
$$

where $\mathrm{I}(\%)=$ percent inhibition;

$\mathrm{Dc}=$ mean diameter of the culture without AENS or Mz;

Df $=$ average diameter of the culture with AENS and Mz.

\section{Evaluation of the effect of AENS on spore germination}

Slides containing the PDA culture media (control) and slides with PDA at different concentrations of AENS and $\mathrm{Mz}$ were inoculated with spore suspensions $\left(4-5 \times 10^{5}\right.$ spores $\left./ \mathrm{ml}\right)$ of each isolate. The slides were placed in a sterile, moistened tray and incubated at room temperature. Each treatment was repeated 3 times. The number of germinated spores was assessed $48 \mathrm{~h}$ after incubation by microscopic observation of the germ tubes on each slide. Percentage of inhibition was calculated at the end of experiment.

\section{Evaluation of minimum inhibitory concentrations (MIC)}

From the linear regression equation between the Neperian logarithms of the abscissa concentrations and the ordinate inhibition percentages, the concentrations reducing growth and germination by $50 \%\left(\mathrm{MIC}_{50}\right)$ and $90 \%\left(\mathrm{MIC}_{90}\right)$ were determined [29].

\section{E. Assessment of the in vivo Effect of AENS on Cashew Tree Plants}

The most virulent isolate was selected for this test. The resulting spore suspension was calibrated using the Malassez cell at $3-4 \times 10^{5}$ spores $/ \mathrm{ml}$. A wetting agent (about $1 \mathrm{ml}$ soap solution) was added to the spore suspension to facilitate adhesion to cashew tree leaves.

The cashew tree plants, each with about 5 to 6 leaves, were previously washed with tap water and then disinfected with a sodium hypochlorite solution $(1 \%)$. They were then rinsed three times successively with sterile distilled water.

The plants were treated with concentrations $C_{1}=500 \mu \mathrm{g} / \mathrm{ml}$ and $\mathrm{C}_{3}=5 \mu \mathrm{g} / \mathrm{ml}$. A control treatment with sterile soapy water was developed. Each treatment was repeated three times. After treatment, the plants were covered with transparent plastic for at least 12 hours.

The next day, the plants were inoculated by spraying with $6 \mathrm{ml}$ of spore suspension solution per plant, i.e., about $1 \mathrm{ml}$ per leaf. Immediately after inoculation, the plants were covered with transparent plastic to allow the maintenance of relative humidity to promote spore germination. The plants were watered every 2 days.

Evaluation of the efficacy of AENS to protect plants or reduce $P$. heterocornis infections was performed by observing symptoms 14 and 21 days after inoculation.

\section{F. Data Analysis}

SPSS 20.0 software was used to perform statistical analyses. The comparison of means was done by Duncan's test at the $5 \%$ threshold.

\section{RESUlTS}

\section{A. Characteristics of Isolates Used}

Pest 12 and 13 showed the highest diameter of growth, 6.0 and $6.9 \mathrm{~cm}$ respectively. ANOVA showed significant difference $(\mathrm{F}=58.3, \mathrm{P}=0.0001)$ among these isolates and pest 14 isolate which diameter of growth was $4.6 \mathrm{~cm}$. The same result was observed with pathogenicity test (Table I).

\begin{tabular}{ccc}
\multicolumn{2}{c}{ TABLE I: DIAMETER AND SEVERITY INDEX OF ISOLATES } \\
\hline Isolates & $\begin{array}{c}\text { Diameter (cm) of isolates } \\
\text { after 8 days of growth }\end{array}$ & $\begin{array}{c}\text { Severity index of } \\
\text { isolates (pathogenicity) }\end{array}$ \\
\hline Pest 12 & $6.0 \pm 0.3 \mathrm{~b}$ & $1 \pm 0.3 \mathrm{~b}$ \\
Pest 13 & $6.9 \pm 0.3 \mathrm{~b}$ & $1.5 \pm 0.3 \mathrm{~b}$ \\
Pest 14 & $4.6 \pm 0.3 \mathrm{a}$ & $0 . \pm 0.3 \mathrm{~b}$ \\
\hline
\end{tabular}

Values follow with same letters, for the same isolate, are not significantly difference at $5 \%$ Duncan threshold.

\section{B. Effect of AENS on Growth of Isolates of P. heterocornis}

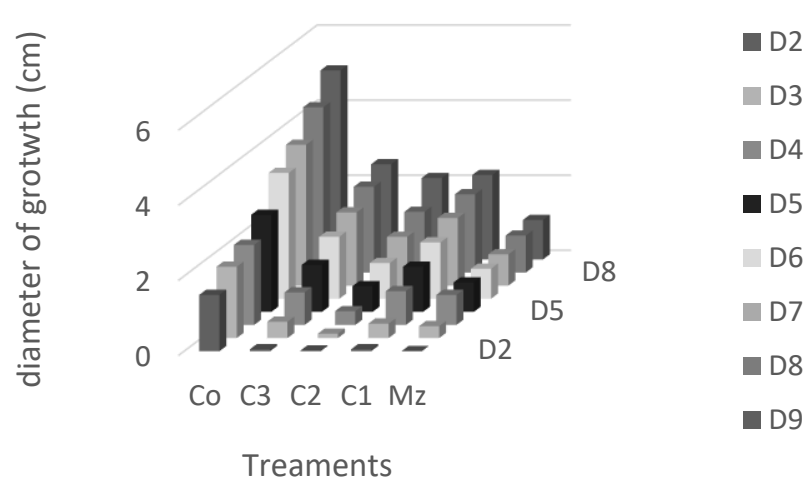

(a)

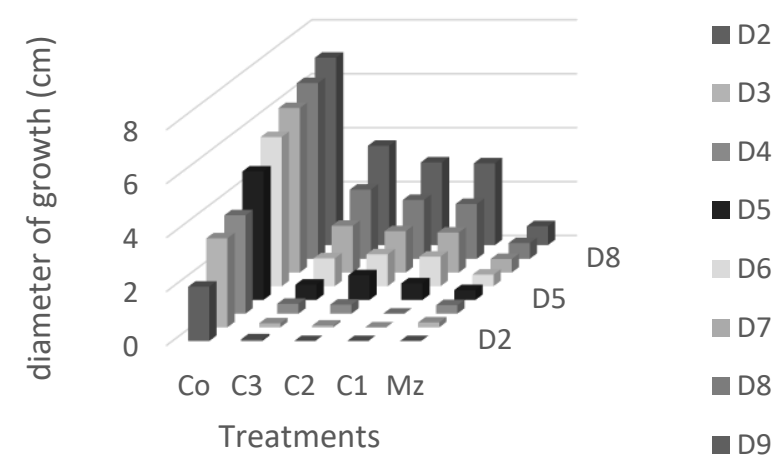

(b)

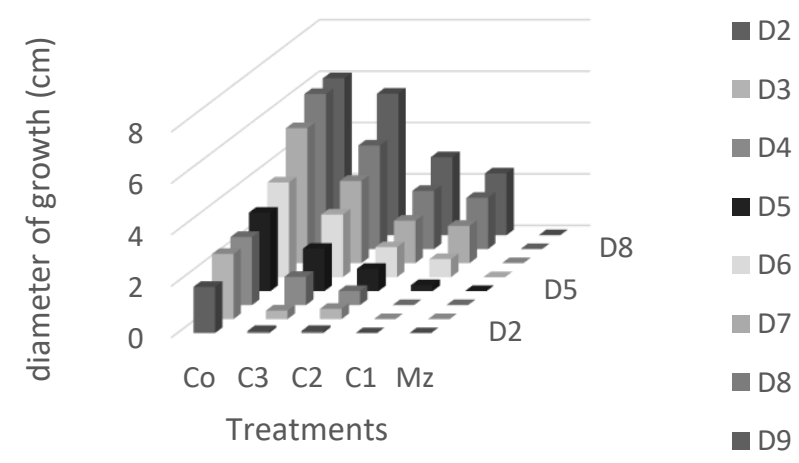

(c)

Fig. 1. Impact of AENS and Mz on growth of different isolates. A) pest 12 ; B) pest 13 ; C) pest 14 . 
A significant difference $(\mathrm{P}<0.05)$ was obtained between different concentrations of AENS and Mz. With all isolates, diameter of growth increase with time (day). But growth was very high with control. Concentration $C_{1}$ and $C_{2}$ reduced growth of all isolates with percentage of inhibition ranged from 53.6 to $73.5 \%$ at day $8 . \mathrm{Mz}$ inhibited growth of isolate with percentage of inhibition of 62.9, 92.3 and $100 \%$ respectively with pest 12 , pest 13 and pest 14 at the end of experiment (Fig. $1 \mathrm{~A}, \mathrm{~B}, \mathrm{C}$ ).

1. MIC 50 and $M I C_{90}$ of AENS on growth of Pestalotia heterocornis

$\mathrm{MIC}_{50}$ obtained was respectively $2.79,1.99$ and $2.41 \mu \mathrm{g} / \mathrm{ml}$ for pest 12 , pest 13 and pest 14 . MIC 90 was ranged from 3.56$4.94 \mu \mathrm{g} / \mathrm{ml}$. The means $\mathrm{MIC}_{50}$ and $\mathrm{MIC}_{50}$ were respectively 2.40 and $4.08 \mu \mathrm{g} / \mathrm{ml}$ (Table II).

TABLE II: MINIMAL INHIBITORY CONCENTRATION (MIC) OF AENS ON GROWTH OF DIFFERENT ISOLATES OF PESTALOTIA HETEROCORNIS

\begin{tabular}{lcccc}
\hline & Pest 12 & Pest 13 & Pest 14 & Mean \\
\hline $\mathrm{MIC}_{50}(\mu \mathrm{g} / \mathrm{ml})$ & 2.79 & 1.99 & 2.41 & 2.40 \\
$\mathrm{MIC}_{90}(\mu \mathrm{g} / \mathrm{ml})$ & 4.94 & 3.56 & 3.74 & 4.08 \\
\hline
\end{tabular}

\section{Effect on AENS on Germination of Spores of $P$.} heterocornis

ANOVA showed significant difference on effect of AENS on germination of spores. Any concentration of AENS inhibited germination of spores of any isolate. However, $\mathrm{Mz}$ inhibited totally $(100 \%)$ germination of spores of all isolates (Table III). In control and with AENS, spores developed germ tubes (Fig. 2 A, C) which were absent with Mz (Fig. 2 B).

TABLE III: PERCENTAGE OF INHIBITION (\%) OF AENS ON SPORE

\begin{tabular}{cccccc}
\multicolumn{7}{c}{ GERMINATION } \\
\hline Isolate & Co & $\mathrm{C}_{1}$ & $\mathrm{C}_{2}$ & $\mathrm{C}_{3}$ & $\mathrm{Mz}$ \\
\hline Pest 12 & $0 \mathrm{a}$ & $0 \mathrm{a}$ & $0 \mathrm{a}$ & $0 \mathrm{a}$ & $100 \mathrm{~b}$ \\
Pest 13 & $0 \mathrm{a}$ & $0 \mathrm{a}$ & $0 \mathrm{a}$ & $0 \mathrm{a}$ & $100 \mathrm{~b}$ \\
Pest 14 & $0 \mathrm{a}$ & $0 \mathrm{a}$ & $0 \mathrm{a}$ & $0 \mathrm{a}$ & $100 \mathrm{~b}$
\end{tabular}

Values follow with same letters, for the same isolate, are not significantly difference at $5 \%$ Duncan threshold.

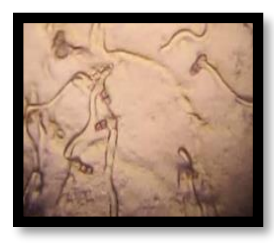

(a)

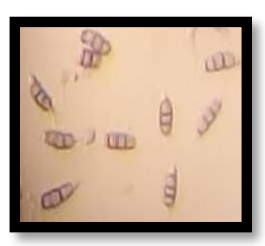

(b)

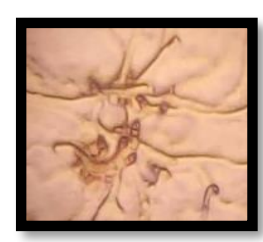

(c)
Fig. 2. Germination of spores of $P$. heterocornis on PDA media supplemented with AENS (a), with Mz (b) and in control (c).

\section{In vivo effects of AENS on Pestalotia heterocornis}

The results showed a clear protection (absence of symptoms) of the plants treated with $\mathrm{Mz}$ (Fig. 3 c). However, At $\mathrm{C}_{1}$ concentration of AENS, 14 days after inoculation, symptoms of pestalotia leaf blight were observed on plants (Fig. 3 b), but less than in control (Fig. 3 a).

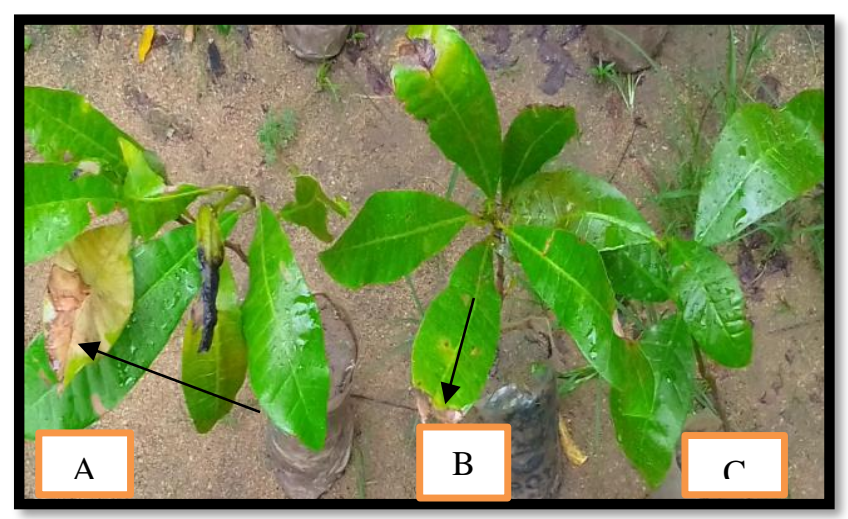

Fig. 3. Cashew plants treated with water (A), AENS (B) and $\mathrm{Mz}(\mathrm{C})$ and inoculated with spores of $P$. heterocornis.

The symptoms obtained from the test were identical to those at baseline and the pathogen reisolated was $P$. heterocornis.

\section{DISCUSSION}

Pathogenicity test revealed that the causal agent of pestalotia leaf blight is Pestalotia heterocornis. This result is in agree with those of [9] and [25] who showed that pestalotia leaf blight is due to pestalotia spp. This fungus has been isolated from many other plants such as olive trees [30], tee trees [25] and guava tree [31].

The morphological characterization of $P$. heterocornis allowed to highlight different isolates in terms of growth in PDA medium. This result indicated genetic diversity in $P$. heterocornis. [32] showed that growth rate is a variable in a single Pestalotia isolate.

AENS inhibited growth of isolates up than $60 \%$ at all concentration used. This result can be explained by the active ingredient azadirachtin from neem which has already showed antifungal property against many fungi. Moreover, plant extract contains more than one antifungal compound such as flavonol and phenol [33]. Plant neem extracts have already showed efficiency against mainly fungi diseases. [19] demonstrated the efficacy of Neem oil aqueous extract in reducing Phytophthora sp. attacks on cocoa pods. Similarly, [34] have demonstrated the efficacy of neem extract on diseases in cherry production. [22] showed that aqueous neem seed extract inhibited growth of Phytophthora megakarya in vitro. Mancozeb $80 \mathrm{WP}$ had inhibited, almost totally, the growth of $P$. heterocornis isolates in vitro. This efficacity of mancozeb on the growth is mainly due to its active ingredient mancozeb and its mode of action on cell division. These results are in agreement with those of [14] who showed the efficacy of carbendazine and propiconazole on the growth of $P$. heterocornis isolates in vitro. In addition, Mancozeb has demonstrated its efficacy on reducing in vitro and in vivo the growth of several other fungi such as Colletotrichum gloeosporioides [15].

AENS did not have any action on spore germination. This result desagree that obtained by [14] who have showed that, essential oil of Ocimum gratissimum totally inhibed spore germination of $P$. heterocornis. Antifungal properties of some plant extracts depend on composition and structure of 
his compounds. Thus, these compounds act directly on pathogens and on spores [35], [36].

However, Mancozeb totally inhibited (100 \%) the germination of $P$. heterocornis spores at all concentrations tested. This inhibition would be explained by the action of Mancozeb on respiration. Mancozeb $80 \mathrm{WP}$ is a multi-site fungicide [37] which acts on enzymatic mechanisms involved in energy production. Contact fungicide are known for their action on respiration through the thiol (sulfur) function, which associates with oxygen and thus limits respiration, essential process of germination. In addition, Mancozeb 80 WP has already shown its effectiveness in inhibiting the germination of spores of many fungi [15], [38].

AENS protected cashew plants against $P$. heterocornis in vivo. Azadirachtin and the others antifungal compounds of aqueous neem extract have reduced development of $P$. heterocornis on the leaves area. Moreover, AENS is known to stimulate production of phytoalexins and activity of enzymes in plant [39], [40]. This result can also be explained by production of phenols and stimulation of peroxydase (POX) and glucanase enzymes activities which enhanced resistance of plant. This result is in agreement with that of [14] who showed, efficacy of Ocimum gratissimum essential oil against $P$. heterocornis in vivo.

The results of the in vivo effect of Mancozeb $80 \mathrm{WP}$, on $P$. heterocornis showed the efficacy of the fungicide against $P$. heterocornis. Plants. The result confirms the preventive effect of Mancozeb 80 WP which is a fungicide of contact against fungal diseases. These results corroborate those of [14] who showed that the Propiconazole protected cashew tree plants against pestalotia leaf blight in vivo.

Several studies have shown that plant extracts or their derived compounds have been used to control fungal diseases in vitro, in vivo and in field instead of chemical compounds [33]. The advantage of plants is the non-toxicity to humans and the environment no-development of fungal resistance and low coast of these extracts

\section{CONCLUSION}

Aquoeus extract of neem seed (AENS) has inhibited growth of $P$. hetrocornis isolates in vitro and protected cashew plants in vivo. Neem extract can be integrated in managing progamm of cashew plants in nurseries.

\section{REFERENCES}

[1] I. B. L. Coutinho, F. C. O. Freire, J. S. Lima, F. J. T. Gonçalves, A. R. Machado, A. M. S. Silva, and J. E. Cardoso, "Diversity of genus Lasiodiplodia associated with perennial tropical fruit plant in north eastern Brazil". Plant Pathol. Vol. 66, no 1, pp. 90-104, June 2016.

[2] F. Marlos, C. De lacerda, F.E. Gomes, B.C. De Abreu, T.J. Prisco, "Physiology of cashew plants grown under adverse conditions" Brazilian Journal of Plant Physiology, vol. 19, no. 4, pp. 449-461, 2007.

[3] E. Lacroix, "Les anacardiers, les noix de cajou et la filière anacarde à Bassila et au Bénin.Projet de Restauration des Ressources Forestières de Bassila, GTZ République du Bénin" pp. 1-75, 2003.

[4] E.K.A. Kouassi, "Contribution à la valorisation des sous-produits agricoles en bioproduits", Thèse de doctorat de l'Université de Toulouse, pp. 1-169, 2018.

[5] Y. Hamawa, A. Dona, O.N. Kanmegne, C. Mbaye, Niwah, J.M.D.K. Awono, P.M. Mapongmetsem, "Effet du poids de noix et de la dose d'engrais sur la germination et la croissance de l'anacardier
(Anacardium occidentale L., Anacardiaceae) dans la savane guinéenne du Cameroun". Afrique Science, vol. 15, no. 5, pp. 302-312, 2019.

[6] E.S.C.A. Dedehou, J. Dossou, M.M. Soumanou, Etude diagnostique des technologies de transformation de la pomme de cajou en jus au Bénin. International Journal of Biological and Chemical Sciences, vol. 9, no. 1, pp. 371-387, February 2015.

[7] O.O. Adeigbe, F.O. Olasupo, B.D. Adewale, and A.A.Muyiwa, "A review of cashew research and production in Nigeria in the last four decades" Science Research Essays, vol. 10, pp. 196-209, 2015.

[8] F. M. P. Viana, J. E. Cardoso, and H. A. O. Suraiva, "First report of a bacterial leaf and fruit spot of cashew nut (Anacardium occidentale L.) caused by Xanthomonas campestris pv. Mangiferae indicae in Brazil". Plant Dis., vol. 91, no. 10, p. 1361, September 2007.

[9] L. C. A. Afouda, V. Zinsou, R. K. Balogoun, A. Onzo, and B.C. Ahohuendo, "Inventaire des agents pathogènes de l'anacardier (Anacardium occidentale L.) au Bénin". vol. 73, pp. 13-19 2013.

[10] E. O. Uwagboe, S. O. Adeogoun, and S. O. Odebode, "Constraints of farmers in cashewproduction: A case study of Orire L.G.A. of Oyo state, Nigeria". ARPN. Journal of A gricultural and Biological Science, vol. 5, no. 4, pp. 27-31, 2010.

[11] N.V. Noiha, L. Zapfack, D. V. Awe, N. Witanou, B. Nyeck, J.D. Ngossomo, M.R. Hamadou, C.D. Chimi, R.B. Tabue-Mbobda, "Floristic structure and sequestration potential of cashew agroecosystems in Africa: A case study from Cameroon" Journal of Sustainable Forestry,vol. 36, no. 3, pp. 277-288, March 2017.

[12] J.P. Ngoh Dooh, D.B.C. Asta, B. Djile, T.D.B. Tchoupou, A. Heu, S.B. Mboussi, T.W.N. Kuate and Z. Ambang, "Major Fungi Diseases of Cashew Trees (Anacardium occidental L.) in Cameroon" Journal of Agricultural Science, vol. 13, no. 3, pp. 124-134, February 2021. DOI:10.5539/jas.v13n3p124.

[13] M. Mazarotto, M.P. Bovolini, M.F.B. Muniz, H.R. Ricardo, L.R.S Reiniger, F. Álvaro, A.F.S. Dos Santos, "Identification and characterization of pathogenic Pestalotiopsis species to pecan tree in Brazil". Brasília, vol. 49, pp. 440-448, 2014.

[14] N. Silué, S. Soro, T. Koné, K. Abo, M. Koné, and D. Koné, "Contrôle chimique et biologique des nécroses foliaires de l'anacardier (Anacardium occidentale L.) en CI. Agronomie Africaine", vol. 30, no. 1, pp. 107-122, 2018.

[15] D. Tonon, R. Sikirou, A.C. Adomou, V. Zinsou, B. Zocli, K. N'Djolosse, and S. Bello, Efficacité des fongicides Mancozèbe $80 \mathrm{WP}$ et Chlorothalonil-Carbendazime $65 \mathrm{SC}$ contre Colletotrichum gloeosporioides agent causal de l'anthracnose de l'anacardier au Bénin. Int. J. Biol. Chem. Sci., vol. 11, no. 5, pp. 2093-2105, Novembre 2017 , DOI: https://dx.doi.org/10.4314/ijbcs.v11i5.13.

[16] M. Ahmad, and M.I. Aril, "Resistance of beet armyworm Spodoptera exigua (Lepidoptera: noctuidae) to endosulfan, organophosphorus an pyroheoid insecticides in Pakistan. Crop prot, vol. 29, no. 12, pp. 14281433, 2020.

[17] J. Wang, J. Li, J. Cao, and W. Jiang, "Antifungal activities of neem (Azadirachta indica) seed kernel extracts on post harvest diseases in fruits. African Journal of Microbiology Research, vol. 4, no. 11, pp. 1100-1104, May 2010.

[18] R.C. Saxena, Insecticides from Neem. In J.T. Arnason, B.J.R.Philogene and P. Morand (eds) Insecticides of Plant Origin.American Chemical Society Symposium series, vol. 387, pp. 110 - 35, 1989.

[19] J. Pohe, et T. Agneroh, "L'huile des grains de neem, un fongicide alternatif de la cacaoyère" Journal of Applied Biosciences, vol. 62, pp. 4644-4652, February 2013.

[20] F. Mamadou, "Nouveau fractionnement de la graine de neem (Azadirachta indica Juss) sénégalais: production d'un biopesticide $\mathrm{d}$ 'huile et de tourteau. Thèse en vue de l'obtention du Doctorat de l'Université de Toulouse, pp. 1-267, 2010.

[21] A.J. Gnago, M. Danho, T.A. Agneroh, I.K. Fofana, et A.G. Kohou, "Efficacité des extraits de neem (Azadirachta indica) et de papayer (Carica papaya) dans la lutte contre les insectes ravageurs du gombo (Abelmochus esculentus) et du chou (Brassica oleracea) en Côte d'Ivoire" International Journal of Biological and Chemical Sciences, vol. 4, no. 4, pp. 953-965, 2010.

[22] S.B. Mboussi, Z. Ambang, and J.P. Ngoh Dooh, "Aqueous extracts effects of seeds of Thevetia peruviana and Azadirachta indicaon the development of Phytophthora megakaryain locality of Biakoa (Cameroon)". Journal of Applied Biosciences, vol. 105, pp. 1004210054, September 2016. DOI: 10.4314/jab.v105i1.1.

[23] O.M. Gupta, S.R. Kotasthane, and M.M. Khare, 1986. "Fusarium wilt of chickpea (Cicer arietinum)" Agricult. Rev. vol. 7, pp. 87-97.

[24] S. S. N. Maharachchikumbura, L.D. Guo, E. Chukeatirote, A. H. Bahkali, K. D. Hyde, Pestalotiopsis-morphology, phylogeny, biochemistry and diversity. Fungal Diversity, vol. 50, pp. 167-187, Aughust 2011 DOI 10.1007/s13225-011-0125-x. 
[25] S.D. Joshi, R. Sanjay, U.I. Baby, A. Mandal, "Molecular characterization of " spp. associated with tea (Camellia sinensis) in southern India using RAPD and ISSR markers" Indian J. Biotechnol, vol. 8, no. 4, pp. 377-383, November 2009.

[26] H. L. Barnett, and B. B. Hunter, " Illustrated genera of imperfecti fungi." 4th edition, MacMilan, New York, USA, 1987.

[27] S.R.Singh, L.E.N. Jackai, G. Thottappilly, K.F. Cardewell, and G.O. Myers, "Status of research on constraints to cowpea production, In Biotechnology: enchancing research on tropical crops in Africa éd, pp. 21-26, 1993.

[28] S. Nyassé, C. Cilas, C. Hérail, and G., Blaha, "Leaf inoculation as an early screening test of cocoa (Theobroma cacao L.) resistance to Phytophthora black pod disease" Crop Protection, vol. 14, pp. 657-663, December 1995

[29] N. Dohou, K. Yamni, A. Badoc, et A. Douira, "Activité antifongique d'extraits de Thymelaea lythroides sur trois champignons pathogènes du riz. Bull. Soc. Pharm. Bordeaux, vol. 143, pp. 31-38, 2004.

[30] M.S.H. Moustafa, A.M. Hala, El-Dakar, and M. A.A. Asmaa, "Pestalotia leaf Spot a New Disease affect Guava Trees in Egyp," International Journal of Scientific \& Engineering Research, vol. 6, no. 10, pp 1306-1312, October 2015.

[31] L.M. Keith, M.E.Velasquez, and F.T. Zee, "Identification and Characterization of Pestalotiopsis spp. Causing Scab Disease of Guava, Psidium guajava, in Hawaii" Plant Disease vol. 90, no. 1, pp. 17-23, 2006. DOI: 10.1094/PD-90-0016.

[32] H.L. Hu, R. Jeewon, D.Q. Zhou, T.X. Zhou, and K.D. Hyde, "Phylogenetic diversity of endophytic Pestalotiopsis species in Pinus armandii and Ribes spp.: evidence from rDNA and $\beta$-tubulin gene phylogenies. Fungal Divers, vol. 24, pp. 1-22, Janvier 2007.

[33] D.S.S. Shuping, and J.N.Eloff, "The use of plants to protect plants and food against fungal pathogens: a review" Afr J Tradit Complement Altern Med., vol. 14, no. 4, pp. 120-127, 2017.

[34] B. Shu, O. Wang, J. Hu, M. Huang, Hu. and G.A. Zhong, "comprehensive etudy on apoptosis induction by azadirachtine in spodoptera frugiperda cultured cell line sf9.Arch Insect Biochem physiol", Arch. Insect Biochem, vol. 89, no. 3, pp. 153-68, 2015.

[35] B. Camara, E. Dick, A. Sako, D. Kone, C. Kanko, M.-A.-D. Boye, S. Ake, and A. Anno, Lutte biologique contre Deightoniella torulosa (Syd.) Ellis, par l'application des huiles essentielles d'Eucalyptus platyphylla F. Muell. et de Melaleuca quinquenervia L. Phytothérapie et écologie, vol. 8, pp. 240-244. July 2010 https://doi.org/10.1007/s10298-010-0568-3.

[36] F. M. Kassi, O. J. Badou, Z. F. Tonzibo, Z. Salah, L. D. G. E. Amari, et $\mathrm{D}$. Koné, "Action du fongicide naturel NECO contre la cercosporiose noire (Mycosphaerella fijiensis Morelet) chez le bananier plantain (AAB) en Côte d'Ivoire". J. Appl. Biosci. Vol. 75, pp. 6183-6191, 2014

[37] FRAC, "Fungicide Resistance Action Comittee. Code List $($ C 2020 : Fungal control agents sorted by cross resistance pattern and mode of action" p.16, 2020

[38] N. Silué, K. Abo, B. Camara, S. Soro, G.M. Ouattara, S. Tuo, M. Koné, and D. Koné, "Effect of some Synthetic Fungicides on the in vitro Growth of Colletotrichum gloeosporioides, Causative Agent of Cashew Tree Anthracnose in Côte d'Ivoire" Asian J. Crop Sci. vol. 9 , pp.149-158, April 2017.

[39] O. P. N. Effa, P. F. Niemenak, M. L. Djocgoue, M. Ondobo, and N. D, "Omokolo, Heritability of polyphenols, anthocyanins and antioxidant capacity of Cameroonian cocoa (Theobroma cacao L.) beans". Afr. J. Biotechnol, vol. 2, pp. 672-268, September 2015.

[40] S. S. L. Surendra, S. Godara, A. Gangopadhayaya, and K.S. Jadon, "Induced resistance against Alternaria brassicae blight of mustard through plant extracts", Archives of Phytopathology and Plant Protection, vol. 45, no. 14, pp. 1705-1714, 2012. 